\title{
Where Thunder Goes to Die: Exile and Frustration of Migration in Esiaba Irobi's Poetry
}

\section{Niyi Akingbe \\ ORCID iD: https://orcid.org/0000-0003-4637-131X}

\section{Abstract}

This article is focused on the analysis of a clash between expectation and reality of failure, suffered by Esiaba Irobi when he fled the frustration and persecution at home in Nigeria to the United Kingdom, on a British Foreign and Commonwealth Office Fellowship in 1989. Irobi was a vibrant Nigerian youth and his (mis)adventures in the United Kingdom when he suffered alienation as an aftermath of racism, marginal sojourn in the United States of America, and eventual death in a German hospital reflects the trajectory of Nigerian youth migration. In a close reading of the possible link between individual's travails and nation-state's disorder, Irobi's turbulent career path at the University of Nigeria, Nsukka ostensibly provides a test case for the analysis of difficulties the teeming Nigerian youth often individually face, when they have to continually contend with paradoxes of the Nigerian experience. Few of the youth who have migrated to other countries have lived this dilemma. Since Irobi's untimely death on 3 May 2010, there have been renewed interests in his writings. Curiously, in death, Irobi's life continues to be celebrated by friends and colleagues from around the world, including from United States of America, the United Kingdom and Nigeria.

Key words: Esiaba Irobi, Nigerian youth, near-impossible exilic experience, racism, Nigerian universities' 'gate keepers', frustration of migration

\section{Introduction}

Esiaba Irobi, a Nigerian poet and playwright, is a unique voice in African poetry, theatre and cultural productions. His tactful exploration of the tension between the ruler and he ruled continues to grow in influences despite his death 
more than a decade ago. Irobi's poetry collections include: Inflorescence (1989), Cotyledons (2009), Rejection Slips (2004) and Why I Don't Like Philip Larkin (2005). By revolving his poetry around the Nigerian nation-state's obvious failings, Irobi launches his angry outbursts against a perceived leadership burden created by the Nigerian power elite. A significant trait of Irobi's disillusionment with the burdensome Nigerian nationhood, is the absolute ease with which he chips away at the certainties that incompetent leadership and unbridled inequality among the federating units have caused the country's ludicrous failings. Overtly acerbic in tone, Irobi's poetry is restlessly expansive in scope, extravagant in depth and violent in expression. The violence imbedded in his poetry, is often inescapably grounded in subversive erudition, biting puns, verbal sophistication and a volley of libidinous metaphors. Irobi was born in 1960 and died in 2010.

Born in the Republic of Biafra, Irobi lived unfulfilled years in exile in Nigeria, United Kingdom (UK), and the United States of America. He fled Nigeria for the UK in 1989 when the Abacha's military regime considered him dangerous and his theatre and poetry subversive. But having fled to the United Kingdom where he thought he could continue with the creative enterprise, fate dealt him crude blows, as exile brought him into collision with a frustrating racism that denied him an appreciative audience and earned him constant rejection of manuscripts by the publishers he approached. Again, exile robbed him a covetous place in the African literary hall of fame, diminished his rambunctious creativity and punctured his boisterous erudition swagger. For a man of immense intellectual resilience, eccentric poetic disposition and spectacular dramatic craftsmanship, when Irobi died in 2010 his fame as an accomplished African poet was yet to be attained. Anticipating his possible canonisation in the annals of African literature, it is no wonder that Irobi has made a striking revelatory premonition in the epitaph etched for himself in 'Finally':

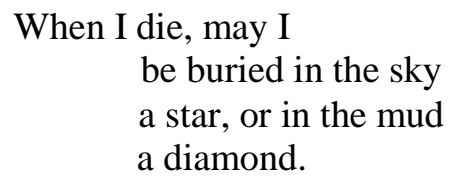

(Inflorescence 1989: 59.)

Sadly, for most struggling writers, when they die suddenly, they slowly fade from the limelight into the expected oblivion. But not for Irobi, as even in 
death, his reputation has grown slowly and steadily as an engaging poet. Interestingly, since his demise, Irobi has been celebrated all over the world. The celebration is often encapsulated in a series of memorial events which have culminated in conferences, lectures, symposia and commissioned biographical projects. Again, reminiscences, epitaphs, eulogies and numerous literary prizes have been named in his memory in different countries of the world, all in the intention of immortalising his unusual, fertile mind. Underpinning the desperation to shake off the engulfing tyranny bred by the pervading mediocrity in the Nigerian university system, immigration to the West offered immediate optimism to Irobi whose academic career was evidently threatened by the overbearing conduct of the self-appointed 'gate-keepers' at Nsukka. The article untangles the contradictory impulses trailing Irobi's anxieties to migrate from Nigeria to the United Kingdom on the one hand, and an evaluation of the attendant difficulties of exile suffered during his turbulent sojourn in the United Kingdom and the United States of America. These difficulties apparently manifested in Irobi's failure to secure job tenure, persistent rejection of his manuscripts by publishers, and inability to secure an appreciative audience for his literary works which eventually diminished his talent as a burgeoning African poet and playwright. Stricken with a sense of failure as an aftermath of the accrued frustrations, his health was harmed which later resulted in his untimely death.

In responding to the theme 'Youth Migration' as essential focus of this article, it is important to state clearly, that Irobi as a youth ventured into migration that took him to the United Kingdom (UK) initially and later to the USA in search of a congenial atmosphere that could nurture his artistic/ creative enterprise. In the light of acute awareness of the trajectories of Irobi's (mis)adventures in the UK, a succour of relief in the USA and eventual death in Germany, it would be appropriate to acknowledge that he is an embodiment of enduring despair, often faced by the Nigerian youth running away from the debilitating social, economic and political complexities ravaging the postcolonial Nigeria. Irobi's unfulfilling aspirations in Nigeria, his migration to the UK, encounters with racism, relocation to the USA, marginal accomplishment and untimely death in a German hospital provides us with a paradigm for evaluating the challenges faced by the Nigerian youth, both past and present.

By establishing a connection between Irobi's plight and the collective dilemma of the Nigerian youth populace, the article strives to draw attention to 
the parallelism between Irobi's trajectory and the collective plight of the Nigerian youth population. Essentially, Irobi's (mis)adventures are harnessed for a reconstruction of how Nigerian youth within the context of individual struggles, social anxieties and paradoxes of the Nigerian experience have continually struggled against negative policies initiated by the successive governments. It is understood that Irobi was driven into exile by the compromised University system and a stifling political climate. He further had to contend with immiserations of alienation, acculturation and 'otherness' as they played out in his host countries. The argument of 'Youth Migration' is strengthened further to portray Irobi as a symbol of the collective dilemma of youth in flight from the dehumanising conditions in Nigeria. Hence, attempt will be made to lay bare how Irobi, stressed by gnawing social anxiety and uncertain career path, but unavoidably conscious of the ominous clash with the military authorities, took a hasty flight out of Nigeria, and the subsequent complications of his exile in both the UK and USA which culminated in his untimely death, as referenced in his poetry.

\section{Youth Migration in the Nigeria Nation-State's Context}

For all its compelling presence in Africa, boisterous population, ethnic diversity and its youth resilience, Nigeria forever remains a complicated and ambiguous nation-state. It is a country stupendously endowed with natural resources, but mismanaged by a successive horde of thieving, predatory rulers. Kempe Ronald Hope has argued that, 'much of Nigeria's corruption is institutionalized. It's built deeply into the system which also makes it systemic' (Hope 2017:138). Consequently, the Nigerian political elite continues to engage in corrupt practices due to the country's weak institutions. Again, postcolonial Nigeria's formation is inherently controversial and, tainted with grandiose subterfuge shamelessly superintended by the British colonial authority. Curiously, its present is marred by violence deriving from political inequality among its federating units and the future of its continuity remains uncertain. Yet, the impact of its prodigious human resources is felt wherever it makes appearance. Consequently, anxieties emanating from the long-running bite of economic difficulties, decades of tyrannical military rule, pretentious democratic governance and overtly mismanaged economy, have conspired to render the youth socially beleaguered in the post-independent Nigeria. Frighteningly, snapping out of lethargy occasioned by unmitigated disillusion- 
ment, the generations of the traumatised youth in quest for better standards of living, have often been forced to migrate to other parts of the world. Nevertheless, millions of the Nigerian youth, who are not fortunate enough to raise the basic travelling costs and are not courageous enough to dare, are still forever trapped in the quagmire of contending with needless police brutality, power outages, insecurity, unemployment, flagrant disregard for the rule of law and are being daily subjected to endure the disturbing realities of humongous corruption perpetrated by the political elite. Perhaps, complications in the Nigerian social and political paradigms would benefit those interested in the state's instrumentalization of chaos and disorder. Apparently, governance in Nigeria like many other post-independent African countries thrives on disorder. Patrick Chabal and Jean-Pascal Daloz refer to 'Disorder' as 'the process by which political actors in Africa seek to maximize their returns on the state of confusion, uncertainty, and sometimes even chaos, which characterizes most African polities' (Chabal \& Daloz 1999: xviii).

But rather than wallowing in unconscionable despair which has driven promising young Nigerian men and women into recurrent suicides, if oppressive policies accrue with impunity, the Nigerian youth as a matter of urgency should have launched a headlong confrontation against the oppressive power elite to demand indisputable probity in governance. Again, if the traumatised Nigerian youth are determined to change the prevailing narratives of economic displacement, the social challenges besetting them are by no means insurmountable. It bears remarking to note that there was an exceptional development to the youth's passivity, if properly harnessed, would have repositioned the Nigerian youth to become active participants in contemporary Nigerian power discourse. However, this opportunity was mismanaged due to lack of experience in the art of organising strategic national protest. For years, the Nigerian police force has failed to tackle headlong the most worrisome demotivation which accrued from poor salary of its personnel and finding a last solution to the dearth of infrastructure which has often hindered effective policing in Nigeria, due to, lack of operational tools to aid a needful gathering of intelligence about operational network for effective handling of the menace of armed robbery in the country. But has never deemed it necessary to put a stop to the activities of the policemen in the SARS unit, who have continually extorted money from innocent Nigerians, majority who are youth. Angers against police extortion and brutality came to a head on October 23, 2020, when Nigeria woke up to what began as 'End SARS' youth protest against a 
long running brutality of the police Special Anti-Robbery Squad. At first, End SARS debuted as a decentralised social movement, and series of mass protests directed against police brutality in Nigeria. As the \# End SARS hashtag went viral, so did the slogan make an urgent call for the unconditional disbanding of the notorious but trigger-happy Special Anti-Robbery Squad. Incontrovertibly, the rogue cops in the SARS unit have killed more innocent youth than the suspected armed robbers in the past years. Naively, the protest lacked ideological direction as it was personalized by a collective of raving hip hop artistes and celebrities in the Nigerian movie industry who initially coordinated it until it was violently hijacked by the hoodlums who resorted into arson and killing of civilians and the police personnel. Sadly, while fashion trends, blockbuster films and new hip-hop acts receive outstanding raves from the Nigerian youth audience, they are forever timid to criticise the obnoxious government policies which tend to mortgage their future. Most unfortunately, rather than standing up against the thieving and oppressive regimes in the country, like their peers in Sudan, Tunisia, Egypt and Lebanon; the Nigerian youth in its unimaginable amazement, continue to embolden oppression by individually acquiescing to different guises of self-help through internet cyberfraud, drug trafficking, armed robbery, ritual-killing, pipeline vandalism, kidnapping and human trafficking.

It ought to be clear now to the Nigerian youth why they urgently need to capture the national narrative from the power elite, as compellingly advocated in the words of Femi Osofisan, a prodigious Nigerian playwright. Osofisan, in an outburst of anger, declaims 'in the plays which I have written onto the bleeding pages of this troubled age, I have sought, advisedly by suggestive tropes, to deny consolation to the manufacturers of our nation's anomy, and at the same time to stir our people out of passivity and evasion' (Osofisan 1997: 24). Sadly, whether in staging national or all-encompassing protest, organising rallies to demand probity and being united to form a vanguard for political liberation, it is doubtful, in anyway, if the Nigerian youth would ever collectively stand up against the oppressive power elite anytime soon. Even though the Nigerian youth have demonstrated coward passivity toward initiating a collective liberation struggle from their oppressive overlords, the frequency of their migrations seamlessly retells how living in present day Nigeria has become undeniably precarious. As long as the postcolonial Nigeria nation-state suffers a stranglehold of retrogression at the hands of its political class, its army of resourceful youth will continue to 
embrace migrations to other parts of the world.

Works on migration often emphasise the biting effects of exile within the contexts of displacement and loss of home. Nana Wilson-Tagoe has summed up this loss in cryptic words in most of the new diasporic texts, migrant experience is defined by tense and conflictual relations to both old and new homes, and it is the productive tensions of these relations that disrupt and re-define the old connections between place, culture, and identity' (WilsonTagoe 2009:15). Irobi's audacious poetics as his subversive dramaturgy, libidinous metaphors, anger and melodrama are all too often variables of the concomitants of his creativity, continue to frighteningly remind us that hope has yielded to despair and, the future does not hold a brighter promise for the vulnerable and disempowered Nigerian youth. These young men and women are living in a failed country, experiencing a leadership crisis of seemingly insurmountable proportions. The possible political fallout from decades of the country's misrule is gradually coalescing into a discursive paradigm of contemporary postcolonial literature, especially fiction, where narratives of stereotypical Nigerian drug dealers, fraudsters and criminals are underpinned to emphasise the failure of its nation-state. For instance, a battered Nigeria image is virulently underlined in its immigrant characters ostensibly steeped in fraud, drug dealings and other criminal activities. These depressing depictions are captured in Zake Mda's She Plays with the Darkness (1995), Patricia Schonstein Pinnock's Skyline (2000), Phaswane Mpe's Welcome to Our Hillbrow (2001), K. Sello Duiker's The Quiet Violence of Dreams (2001), Kgebetli Moele's Room 207 (2006), Teju Cole's Every Day is for the Thief (2007) and Open City (2011), Niq Mhlongo's After Tears (2007), Heinrich Troost's Plot Loss (2007), Andrew Brown's Refuge (2009) and Yewande Omotoso's Bom Boy (2011).

A juxtaposition of the Lagos pandemonium and New York's social upheaval where the Nigerian characters are enmeshed, constitute the narrative building-blocks of Teju Cole's Every Day Is for the Thief and Open City. However, while Omotoso's novel is imbedded in Afropolitanism that seeks to interlock differing identities for a reconstruction of the country's dented image, the other aforementioned novels laboriously focused on single characters as representatives of Nigeria. Of key importance is the way these other novels vehemently deplore grotesque imageries to illustrate and reiterate Nigeria's failings as externally exhibited by its criminal nationals in some foreign countries. Commenting on the negative caricaturing of Nigerians in these 
novels, Rebecca Fasselt has argued that 'although Nigerians experience less literal, physical violence, discursive violence directed against them appears all the more intense, drawing on a global archive of denigrating representations of their people' (Fasselt 2015: 122). Despite a linear representation and obvious misappropriation of mass hysteria which 'Nigerian' has undeservedly attracted, the failings alluded to in these novels further re-contextualise Nigeria as an unstable country, reeling under the siege of Boko Haram terrorists, itinerant bandits, serial kidnappers and marauding gangs of the murderous Fulani herdsmen. In the background of investigations into the depredation of Nigeria lies a delineation of its leadership crisis tellingly examined by Chinua Achebe in The Trouble with Nigeria, where he argues that:

The trouble with Nigeria is simply and squarely a failure of leadership. There is nothing basically wrong with the Nigerian character. There is nothing wrong with the Nigerian land or climate or water or air or anything else. The Nigerian problem is the unwillingness or inability of its leadership to rise to the responsibility, to the challenge of personal example which are the hallmarks of true leadership (Achebe 1984: 1).

Engaging the Nigeria nation-state's failings, Irobi's poetry uncannily yet vociferously untangles a disintegrating country where violence takes place against a background of kidnapping and extra-judicial killings by the government forces and ethnic militias. The Nigerian youth equally suffer poverty, neglect and are helplessly trapped in a collapsing economy. Most recently, the youth have been scandalised by the confounding complexities of migration underlined when many have died in their thousands each year while attempting to cross the death-trapped Sahara desert to Europe to seek an ostensibly more fulfilling life. The magnitude of the woes of Nigerian youth is captured in Irobi's 'The Kingdom of the Mad':

I spit upon the laws that thieves have made

To give the crooked the strength to rob the straight

I spit upon a country so full of wealth

Yet millions wallow in squalor and in want.

I spit upon the flag that flaps like a rag

On an iron pole planted on the vision of pregnant generals. 
I spit upon rabid religions that defend a hell on earth And preach a heaven beyond this mire I spit upon the education that turns into stenographers A generation that could have been philosophers visionaries and revolutionaries. Upon this whole damned nation of mine do I spit. And while I spit, I weep.

(www.sentinelpoetry.org.uk, July 2010.)

The fact that Irobi could in the poem, reflect on the youth's predicaments in the 1990s draws our attention to his self-awareness of the prevailing difficulties which have impugned self- realisations of the teeming Nigerian youths. Based on this understanding, there really should be little doubt in anyone's mind regarding his unconditional commitment to the total emancipation of the youth and a recuperation of the nation's narratives from the clutches of its predatory political elite. As the Nigerian youth is hopelessly stranded in this fragmentary contraption called a nation, its enormity is precariously amplified in the correlation between retrogression and liberation. Consequently, a quest for Nigerian youth's liberation from the stranglehold of visionless leadership is apprehended when Irobi exuberantly lamented in the 'The Wall':

THE TALLER TREES

gigantic in their height,

$$
\begin{aligned}
& \mathrm{S} \\
& \mathrm{T} \\
& \mathrm{A} \\
& \mathrm{N} \\
& \mathrm{D}
\end{aligned}
$$

in the best places in the sun.

$$
\text { UNDER }
$$

their canopies and shadows,

THE CREEPERS,

wriggling, crawling, rolling,

WEARY WITH TOIL,

The creepers, men like me,

THE EXILE;

I leave to live, I exit to exist.

(Cotyledons 2009: 23.) 
Irobi in the poem, invites us to have a look at the collective plight of the Nigerian youth struggling under the yoke of oppressive geographical space managed by directionless successive Nigerian governments. Now fed up with a ceaseless struggle to survive in the Nigerian suffocating space, Irobi unleashes his determination to 'leave' the country in order to continue 'living' through an 'iconology of the text'. W.J.T. Mitchell has described 'Iconology of the text' as a linguistics of the image which 'deals with such matters as the representation of objects, the description of scenes, the construction of figures, likenesses, and allegorical images, and the shaping of texts into determinate formal patterns' (Mitchell 1994: 112). Irobi's poetry offers unbiased interpretation of the country's precarious situation and forces us to confront point-blank the unpleasant choice the youth have to take, either they continue to endure the tragedy of living in a failed country or take a flight to the next available country, where their dreams could be realised. Whether taking a flight into exile or exploring an alternative course of action that leads to a circumvention of societal ethics, the Nigerian youth is trapped in the terrible dilemma of struggling to find a meaning to the ragged life superintended by the thieving political elite. His insistence on the need for good governance which could guarantee a meaningful life for the future generations of the Nigerian youth population, invokes a conviction that Irobi has identified with one of the most vulnerable social groups which is always at the receiving end of the sustained selfish interests of the Nigerian power elite.

\section{Irobi's Anxiety in a Rundown Nation-state}

Placing Irobi's tragedy of exile and frustration of immigration that contributed to an untimely hastening of his death, in its broader social context, it becomes imperative to account for the role of the military in the destruction of the Nigeria nation-state which forced him into exile. Exploring Irobi's poetry, one constantly encounters Nigeria being rendered as a set of fragments constituted by its disparaging federating units whose affairs have been constantly manipulated by the minority Fulani power elite since the country attained independence in 1960. Irobi essentially portrays in Cotyledons and Inflorescence 'a haunting canvas of desolate Nigerian landscape, trapped in a forlorn trajectory of perennial systemic failures in its tortuous nationhood' (Akingbe 2014: 15). Buoyed by the deplorable British colonial mendacity and hurtful politicking, for decades, the Fulani group in collaboration with the 
Hausa oligarchy has unfairly dominated the armed forces which plunged the country into an avoidable civil war, between 1967 and 1970. Nigeria's political domination is further illustrated by Pius Adesanmi, when he scathingly remarked that, the alliance of the Fulani minority and the Hausa majority is forged in the oppressive wielding of hegemony fabricated in Hausa language to a frustrating extent, to process a 'Northern oligarchy whose civilian and military arrowheads have maintained the whole of Southern Nigeria in internal bondage since independence' (Adesanmi 2002:130). Unfortunately, the civil war was a genocide programmed towards the mindless killing of two million people, the majority of who were of Igbo extraction. Lamenting expediency of an orchestrated genocide perpetrated against the Igbo by the Nigerian nationstate, Arthur Nwankwo has emphasised that 'genocide is the systematic and calculated extermination of a race or a nation'.

Between May and October, 1966, ‘30,000 Biafrans were tracked down and massacred cold bloodedly in several planned outbursts of Northern [Nigeria] savagery' (Nwankwo 1967:25). The war has regrettably displaced the Igbo from the Nigerian political reckoning and consigned them to a bewildering political wilderness. Remarkably, the civil war references the Igbo's historical experience of confrontation, injury and exclusion from the political mainstream. However, in spite of its defeat and prevention from breaking away as a sovereign Republic of Biafra in 1970, it bears remarking that the Igbo people have 'created' themselves under the most difficult circumstances. They did so in the context of wading through different stages of the state-sponsored devaluation coordinated by the successive Nigerian governments ranging from the military to the pseudo-democratic governments of Shehu Shagari, Olusegun Obasanjo, Musa Yar' Adua. Despite Fulani-Hausa oligarchies and uninformed Western pundits' undying optimism for what Nigeria could be, to the Yoruba, Igbo (the southern Nigeria majorities) and minorities like Ijaw, Urhobo, Efik, Itshekiri, Ibibio alongside the Middle-Belt minorities who constituted the most affected, and recent casualties of the murderous Fulani herdsmen's genocide, Nigeria's nationhood is but a lost project. This implies that these Southern and Middle-Belt federating units do no longer believe in the sovereign continuity of an inequitable geographical contraption called 'Nigeria' but are only and presently enduring the purported genocidal annihilation policy (considering the unchecked, ongoing genocidal killings by the murderous Fulani herdsmen in Nigeria) of Muhammadu Buhari for the time being. Interestingly, Irobi is a member of the marginalized Igbo 
group, less wonder why he has consistently given voice to the marginality and persecution of the Igbo in his poetry.

By continually identifying with the Biafran nation-state rather than Nigeria in his poetry, Irobi tends to portray the Igbo as resilient, entrepreneurial, determined, strong-willed but persistently persecuted and short-changed in the unworkable Nigerian federation. The dubious prosecution of the civil war has paved way for unexpected seizure of political power by the Fulani and Hausa ethnic dominated army which ruled the country for more than thirty years. This domination is further illustrated in the words of Niyi Akingbe 'Irobi has reconfirmed in Why I Don't Like Philip Larkin that the absolute power wielded by the Hausa-Fulani ethnic group of northern Nigeria has ostensibly fuelled Nigeria's inequitable power equation. This inequity has significantly robbed the nation-state of its shine' (Akingbe 2020: 123-124). Given the proven trajectory of the Nigerian military's fetishization of bureaucratic mediocrity, privileging of nepotism above merit, poor fiscal management of the economy, ethnicization of the political appointments, destruction of political institutions, corruption, centralisation of governance and hypocritical meddlesomeness in the University's administration are just some of the ways in which the long years of military rule has compromised the Nigerian nationhood. The undeniable political fallout from the successive military administrations' incompetence is the alteration of power relations among the federating units as it unabashedly promoted the interest of northern Nigeria above the interests of other federating units. Unfortunately, the real casualties in this historical experience are the millions of beleaguered Nigerian youths.

\section{Irobi in the Grip of Academic Tyranny and a Flight into Exile}

Refusing to bend under pressure, Irobi's artistic creativity is forged into a striking, compelling literary brand in the rancorous Nigerian University's system, bristling with belligerence deriving from damning intellectual pretensions. The scope and extent of pervading corruption in the last 30 years has undoubtedly shaken the Nigerian university system to its foundations. Glaring maladministration, undeniable political fallout from the destructive years of military rule has bred a compromised University system engulfed in a thick fog of mediocrity. The debased system has relentlessly churned out a retinue of pseudo-academics whose appointments, promotions and retention of positions are not based on merit but are only derived from the pernicious 
clientage and patronage supervised by the corrupt Nigerian University's administration. Irobi received his Bachelor's and Master's degrees from the University of Nigeria, Nsukka, where he started a career as Graduate Assistant and subsequently had a running battle with some less productive academics, he described as 'Imbeciles', 'absolute cunts!', 'Scavengers loitering around looking for putrid flesh' and 'Accursed vultures!' (Oguibe 2014:3). These pseudo-academics were hell bent on ruining his prodigious intellectual aspiration and enormous amount of talent. According to Olu Oguibe, Irobi was one of the most well-read individuals, whose familiarity with global literary trends was awesomely breathtaking. If Irobi's poetry is committed to the criticism of the Nigeria's leadership deficit, lampooning the anomalies of inequity among the federating units remained his abiding devotion. Surprisingly, his greatest work as a poet: 'Judy', 'Soniya', 'Frankfurt' and 'Mabera'; and as a playwright: Nwokedi, Hangmen Also Die and Cemetery Road were written during the difficult days at Nsukka while he was in his twenties, before a flight into exile (Oguibe 2014: 7).

Weaned on the diets of African literature/criticism, the ostensible intellectual ambience at the University of Nigeria, Nsukka afforded Irobi the needed space to hone his creative prodigy and cultivate a toga of Bohemian eccentricity. Between 1986 and 1989, Irobi succeeded in proven his commitment to artistic creativity by emerging through his works as a promising poet, playwright, actor and theatre director. Although he submitted at least two full-length manuscripts in both the poetry and the drama categories to the annual award competitions run by the Association of Nigerian Authors, he would always end up a runner up, but never a winner (Oguibe 2014: 5). Akingbe (2020: 114) has explained the probable reasons for Irobi's limited critical evaluation and referencing by the critics and scholars of African literature:

A hangover from bric-a-brac of tempestuous disposition aside, Irobi's literary visibility has long been somewhat obscured by the local publication outlets that published most of his plays and poetry collections. For instance, bulk of his works were published by ABIC BOOKS, a rundown oulet in the eastern Nigerian town of Aba. Correspondingly, thematic trajectories of Irobi's plays, similar to his poetry, are foregrounded in a tapestry of ribald jokes and slanderous anecdotes that are garnished with frightening historical asides, a striking valor he shares with Zimbabwe's Dambudzo Marechera. 
Affirming Irobi's dedication to creative writing, Georgina Alaukwu-Ehuria enthuses 'I knew for certain that Esiaba was possessed by his genius. I saw him write for days in hidden corners of the Paul Robeson Drama Building, unkempt and without food .... He would spend his entire money on the purchase of writing and typing sheets, biros ...' (Alaukwu-Ehuriah 2014: 29). An affirmation of Irobi's flirtation with artistic creativity and a dedication to a voracious reading habit by both Oguibe and Alaukwu-Ehuriah tends to reconcile the tensions between the personal and the collective spheres. This resolution is stridently imbedded in the words of Kadiatu Kanneh 'personal and collective histories survive mortality and repeat, through the aegis of geography and descent, a returning of unspent emotion. An intense focusing on spatial metaphor enacts a poetry of place where suffering and desire continually delineate physical space' (Kanneh 1998: 118).

Like Dambudzo Marechera, Irobi's poetry is full of humour, ironic vibes and ostentatious stylistics which exude obscene and libidinous poetics. According to Emmanuel Obiechina 'there is no better way of knowing people than by their words... The personalization of expression and the saturation of words with the inner distinguishing characteristic of personality-is one of the essential marks of modernity in language' (Obiechina 1975: 184). Irobi's personality is encountered in his words as succinctly exemplified in the narrative of his experience at Nsukka while studying for the graduate programme in the 'Homecoming':

I was ruining my eyes as a graduate assistant devouring the classics, minting plays; where I was wasting my youth writing poetry while other more intelligent lecturers were busy researching the profundities of older professors' wives', examining the cleavages of female undergraduates, writing new courses in condom management and bed technology. Eggheads, great eggheads, cracking their shells with glee, spilling their contents, albumen and yolk, day and night, while I ....

(Why I Don't Like Philip Larkin, 2005:85.)

Even though Nigeria stands out as one of the major beneficiaries of the legacies of Colonial education, little has survived; the core values of the university education have been eroded and bastardised by the long years of military rule. Going by its demographics in the last 20 years, it bears remarking that while 
few of the Nigerian academics have distinguished themselves in their chosen fields, a significant number are regrettably wishy-washy and their visibility is by no means sustained through the campus politicking. Specifically, Irobi's was persecuted at the University of Nigeria, Nsukka by the self-appointed 'gate-keepers', men who once were just as bright in their own youth, perhaps not quite as talented, yet full of energy and promise 'but who, with time, had lost the will to excel and eventually retired to the little fiefdom of the academy, whence to wield their cudgels at the younger talents who reminded them of their own earlier promise and, perhaps more poignantly, their failure to reach that promise' (Oguibe 2014: 3). Beyond palpable multileveled tyrannies unleashed on the aspirations of promising academics, a persistent devaluation of the Nigerian University system has been retained as a tradition by the successive military and pseudo-democratic Nigerian governments. A perceptible scenario of the devalued Nigerian university system has been egregiously captured in the words of Pius Adesanmi:

... the Nigerian university faces very serious problems today. The lack of autonomy coupled with grave underfunding has led to infrastructural collapse. The result is the massive brain drain we have witnessed since the mid-eighties ... that the Nigerian scholar who resists the urge to relocate to Euro-America has become an SWD, my acronym for Scholar Without Discourse. Lacking access to current journals and publications, too impoverished to attend conferences, he can no longer keep abreast of discursive developments in his field. Survival forces him to venture into off-campus business endeavours. He increasingly skips classes. His idle students have more than enough time to join campus cults and unleash violence on their fellow students ... (Adesanmi 2002: 116).

Frighteningly, if the successive Nigerian military regimes have collaterally ruined the British-midwifed university system's core values by deliberately starving it of the needed funds, the destruction is further complicated when successive civilian governments appoint incompetent individuals (some unethically and illegally appointed after retirement) with inferior qualifications, questionable moral, academic backgrounds and doubtful sanity as the universities' administrators otherwise called Vice-Chancellors - appointment ridiculously based on party affiliations! Evidence abounds where these Vice- 
Chancellors, in cahoots with rank-shifted, pseudo- intellectuals have through their incorrigible actions committed a wide range of the most condemnable acts abhorrent to the ethics and values of the university system globally, through an organised stealing of the limited funds allotted for infrastructural projects, engaged in the clandestine sales of students' admission slots, perverted the standards to help further careers of their cronies, bastardised a well-ordered academic ordinances and persecuted dissenting voices who frown at these arbitrariness. Most unfortunately, the Nigerian universities have witnessed a steady dramatic decline in quality assurance and academic contents in the last two decades. Rather than being guided by the globally acceptable standards, appointments, assessments and promotions are now premised on the whims of the incompetent and fraudulent Vice-Chancellors within the context of prebendal incestuous arrangements. Suffice to say that the highly toxic Nigerian University system has driven many budding academics and writers into exile in the past years.

Arguably, the extremely harsh and malicious Nigerian University system is an unfortunate by-product of the prevailing failings of the Nigerian nation-state. The corrosive effects of arbitrary persecution of dissent voices in the Nigerian Universities brings forth a critical understanding on why Irobi finally opted for a life in exile. At the risk of been often misconstrued as controversial by the Nigerian captive populace and having been deliberately labelled intellectual jingoists by the successive Nigerian governments, the leadership of Academic Staff Union of Universities (ASUU) has continually stood up for scores of persecuted academics and, often resisted the tyrannies needlessly unleashed by the overzealous universities' administrators'. It becomes strikingly important to state that over the years, ASUU's persistent interventions have been significantly felt in the areas of advocacy for the university's autonomy, checkmating of the excesses of the reckless universities' administrators, drawing attention to corruption in particular universities, a demand for infrastructural upgrading and criticism against perceived pernicious policies which tend to undermine the already fragile funding, has to a reasonable extent mitigated a total collapse of the Nigerian University system in the past decades.

Years of infrastructural decay, poor salary structure, hostile working environment, creeping mediocrity and overbearing tyranny unleashed by the manipulative, schizophrenic Universities' administrators with deranged gestures, keep on driving vibrant Nigerian academics into exile. Commenting 
on a mass exodus of African intellectuals, Charles Larson reiterates that intellectuals and 'writers are denied social and political stability, and their lives are threatened by censorship, forced exile, imprisonment and worse' (Larson 2001: 155). In the foregoing, there is increasing evidence that Irobi and many other Nigerian academia and writers fled the inimical Nigerian university's system characterized by ostentatious tyranny and gratuitous persecution as an aftermath of a collapsed Nigerian political system.

While Irobi seems to somewhat manage the accrued tyranny unleashed on him by the compromised Nigerian university's system, until his play The Hangmen Also Die attracted the attention of the Nigerian army Intelligence unit towards his direction. The play was written and directed shortly after the killing of the Ogoni's minority rights activist, Ken Saro-Wiwa, who was killed by hanging, ordered by the Abacha's military regime. For Irobi, the arrest and persecution proved to be daunting and was the catalyst for a final push into exile. Understandably, in Nigeria and other African countries where authoritarian leaders hold sway, 'writers and artists in general, with their visionary capabilities, are represented as threats to the postcolonial governments' (Toivanen 2011: 25). Echoing a moment of suspense before his departure from Nigeria, Irobi described his horrific encounter with the soldiers who came to harass him at Nsukka in 'Horizons! Horizons!':

HISTORY, FOR ALL EXILES, begins in flight! Georgina, When I ran past you, that Thursday evening, at Lagos, my sandals in my hands, my suitcase on my head, towards Mortal Mohammed airport, on my way to Heathrow, I was not fleeing for my life or from you, far from it, I was fleeing from the myriad indignities I had suffered, recusantly, at the hands of the Beasts of Sandhurst:

Their violent signatures on my skull. The scars on my soul. The sores blooming like sunflowers on this blistered piece of earth you could have mistaken for what was once my heart. The carrion flies buzzing. Their symphony? Hannibal's Halleluyah! And so, this epic is not about: Who was right or wrong? But, how and why it happened: Why I had to flee the land.

(Why I Don't Like Philip Larkin 2005: 82.)

The harassment of Irobi by the soldiers in the poem adds a distinctively politi- 
cal dimension to the already built up turmoil pervading the Nigeria University system. A narrative of assault in the poem is further premised on the repressive politics as it affects the African writers. Looking at the constant harassment, incarceration and killing of writers by the dictatorial regimes in Africa, Charles Larson observes that 'the end of the twentieth century has not been a particularly salutary time for many non-western writers...African writers have suffered more indignities, threats, humiliations and genuine terror than their counterparts in the rest of the non-western world' (Larson 20011: 14-115). It is only fair to say that Irobi's hasty exit from Nigeria was finally triggered by the indignities he suffered at the hands of the repressive soldiers who were determined to stifle all voices of dissent against the reprehensible dictatorship of Abacha.

\section{Constraints, Frustration and the Death of Esiaba Irobi in Exile} In 1989, Irobi arrived in the UK and headed to Sheffield for a doctoral programme. As the excitement of having escaped from the difficulties in Nigeria began to subside, he started to confront the European social challenges early enough and, while doing so, shockingly discovered that the Nigerian cultural environment filled with unusual communal warmth is different from the English society where individualism tends to hold sway. Commenting on the cultural shocks the migrants usually encounter in their new places, James Clifford opines that these migrants constantly contend with 'displaced histories, sites of displacements, interference and interactions [which] come more sharply into view' (Clifford 1992: 109). No sooner had Irobi settled down in the United Kingdom, he started contending with social and racial issues that would have a long-lasting impact on his career and his later health. Illustrating the impact of racism on human relationship, Akingbe and Adeniyi have observed that 'human constructs have impeded cultural encounters, nay harmonious human relations, in culturally polyvalent spaces of the world...to draw attention to the plight of immigrants, migrants, refugees and other people with 'nomadic' condition or consciousness in their host countries' (Akingbe \& Adeniyi 2017: 39). Suffice it to say that Irobi's fortuitous contact with the Western world oscillated between identification and alienation which abundantly afforded him a platform for [re]constructing and analysing his seemingly contentious experiences in his latter works like Rejection Slips and Why I Don't Like Philip Larkin. Recalling the attendant psychological upheavals that revolve around immigration, migration, exile and alienation, 
Sanya Osha has reiterated that 'For the exiled writer or intellectual, exile of course cannot be a state of satisfaction...Exile is essentially a painful separation from one's roots and its damage can be viewed from both personal and social angles' (Osha 1998: 178). Central to the foregoing in the recent time, is the blurring of boundaries between immigration and alienation which has given rise to a body of literary writings that contextualises the themes of belonging and rejection. While most people from the non-European countries are becoming obsessed with the intention of immigrating to the European continent in order to escape from the economic and political difficulties in Africa, the Caribbean, the Middle East and Asia, the ultra-right European activists perceive this movement a social threat. Carla Calarge has argued that:

When clandestine immigrants dream nowadays of the European continent as a paradise or as an El Dorado, their dreams denote a commonly held belief according to which humanity is divided into two large groups separated by an ocean of differences and a wall of quasiinsurmountable obstacles. On plenitude, while, on the other, one finds humanity's outcasts whose existence and lives seem to be of no interest to anyone (Calarge 2015: 5).

A lot of factors are responsible for the turbulent sojourn of Irobi while on exile in the UK. The first has to do with a confrontation headlong with racism while working as a lecturer in the Drama Department at Liverpool John Moores University. Another reason has to do with his being isolated in Sheffield rather than London, which has vast and vibrant theatre outlets. This isolation dampened his inability to direct plays which could have projected his career as a theatre director. Other reasons would be that Irobi's concentration on poetry and drama without giving considerable attention to creative writing in fiction could have also contributed to his inability to secure a reading audience. Another possible reason derives from his decision to pursue scholarship rather than embracing creative writing as a full-time occupation like Buchi Emecheta, Biyi Bandele or Ben Okri and other successful Nigerian writers living in the UK. Apparently, occasion arose where there was the inevitable showdown, in which Irobi needed to stand his ground against the diminishing racism in the UK. This unsavory experience is strikingly referenced in a poem entitled 'An African Poet in England Curses His English Head of Department': 
My dear H.O.D, i.e., Head of a Donkey

May your students mistake you for Caligula or Grendel or the Cyclops or Nero or Nebuchadnezzar or Jack the Ripper or Richard West or Jeffrey

Dahmer and deal with your accordingly.

When you bid the earth adieu, preferably by stoning or public strangling, may you be buried in the belly of a thousand wolves and foxes and hyenas and other scavengers. May vultures share your flesh shred by shred As they sing their national anthem in German

(Rejection Slips 2004 www.othervoicepoetry.org/vol9/irobi/.)

The poem underlines Irobi's protest against racial stereotyping which was probably meted out to him by the aforementioned Head of Department lampooned in the poem. Niyi Akingbe has described protest as 'an expression of opposition or dissent, protest involves an overt response to articulations of power and authority and, assumes the existence of social, political and economic relationships in which individuals or groups disagree with one another, and go on to express such disagreement in a variety of ways' (Akingbe 2011: 5).For lack of visibility in the England's literary circles, Irobi also failed to attract the much-needed audience for his poetry and plays. Finally, he sent manuscripts of his new works to the publishers which were rejected in quick successions. This has been humorously referenced in a poem entitled 'A Frustrated African Poet Curses His Publishers'.

All you shit-faced publishers who thought I was finished who tried to dampen my spirit and cripple my soul with your lorry loads of rejection slips, watch out!

the hibernating bear with real fire in his belly and a bellow as terrifying as a tornado approaching you in a car with a broken windscreen along the expressway somewhere in New Mexico near the Grand Canyon. I have been sleeping now for seven years...

(Rejection Slips 2004 www.othervoicepoetry.org/vol9/irobi) 
Commenting on Irobi's exilic experiences, Olu Oguibe has acknowledged that 'if the cold shoulder of exile nearly put paid to Irobi's art, his experiences in Liverpool also damaged his health, and by the time he arrived in New York in 1997, he was battling chronic blood-pressure problems that put him on constant medication and required exercise and diet regimens' (Oguibe 2014:15). From the foregoing, immigration provides a context-sensitive paradigm for the interpretation of the multiplicity of meanings imbedded in Irobi's exilic years in the UK.

\section{Conclusion}

The article has examined how immigration and exile have significantly affected Esiaba Irobi's art, career and health that finally led to his death. Irobi was a resilient Nigerian youth whose trajectories and (mis)adventures in the UK, USA and death in Germany have been harnessed in the article as a test case, to illustrate the collective anxieties, social depravities and paradoxes of the Nigerian experience which the youth populace, have continually contended with. These developments have often forced them to embark on continued immigrations to different countries of the world where they could realise a fulfillment of their individual aspirations.

Irobi was a prodigious and vibrant Nigerian poet and playwright whose work was obscured by the poor publishing houses. His work espouses a committed rigour grounded in verbal erudition as it overtly subscribes to the deployment of libidinous metaphors. Irobi's poetry, as do his plays, revolve around the Nigerian leadership's deficiencies, the marginality of his Igbo group and concerns itself with the frightening despair of the youth population. Irobi started his career as a lecturer at the University of Nigeria, Nsukka where he had unpleasant time dealing with the mediocrity and intellectual pretensions of the self-appointed 'gate keepers', thrown up by the compromised Nigerian University system. He was finally forced into exile by the Sanni Abacha dictatorship which further stifled dissenting voices at the university. The article has affirmed that while in exile in the UK, Irobi experienced racism first-hand, his art failed to secure a reading audience, and he suffered repeated rejections by the publishers. The culmination of all these experiences led to his failing health which eventually hastened his death. 


\section{References}

Achebe, C. 1984. The Trouble with Nigeria. London: Heinemann.

Adesanmi, P. 2002. Europhonism, Universities and Other Stories: How not to

Speak for the Future of African Literatures. In Falola, T. \& B. Harlow (eds.): Palavers of African Literature. Asmara: Africa World Press.

Akingbe, N. 2011. Social Protest and the Literary Imagination in Nigerian Novels. Saarbrücken, Germany: Lap Lambert Publishing.

Akingbe, N. 2014. Halting a Wilful Degeneration into the Abyss:

Rhapsodizing the Morass of Despair in Esiaba Irobi's Inflorescence and

Cotyledons. K@ta: A Biannual Publication on the Studies of Language and Literature 16,1: 15 - 22.

Akingbe, N. \& E. Adeniyi. 2017. 'Reconfiguring Others': Negotiating Identity

in Chimamanda Ngozi Adichie's Americanah. Rupkatha Journal on

Interdisciplinary Studies in Humanities 9,4: 37 - 55.

https://doi.org/10.21659/rupkatha.v9n4.05

Akingbe, N. 2020. Divided We Stand: Bewailing Alien-nation in Esiaba Irobi's Why I Don't Like Philip Larkin. Kritika Kultura 33/34,1: 111 135. https://doi.org/10.13185/KK2020.03306

Alaukwu-Ehuriah, G. 2014. Esiaba Irobi and His Muse. In Isidore Diala (ed.):

Syncretic Arenas: Essays on Postcolonial African Drama and Theatre for

Esiaba Irobi. New York: Rodopi.

Brown, A. 2009. Refuge. Cape Town: Zebra.

Calarge, C. 2015. Clandestine or Conquistadores? Beyond Sensational

Headlines, or a Literature of Urgency. Research in African Literatures 46,2: 1 - 14. https://doi.org/10.2979/reseafrilite.46.2.1

Chabal, P. \& J. Daloz. 1999. Africa Works: Disorder as Political Instrument. London: James Currey.

Cole, T. 2007. Every Day is for the Thief. Lagos: Cassava Republic.

Cole, T. 2011. Open City: A Novel. New York: Random House Publishing Group.

Clifford, J. 1992. Traveling Cultures. In Lawrence Grossberg, Cary Nelson \&

Paula Treichler (eds.): Cultural Studies. New York: Routledge.

Duiker, K. S. 2001. The Quiet Violence of Dreams. Cape Town: Kwela.

Fasselt, R. 2015. 'Nigeria' in the Cape: Afropolitanism and Alienation in

Yewande Omotoso's Bom Boy. Research in African Literatures 46,2:119

- 145. https://doi.org/10.2979/reseafrilite.46.2.119 
Hope, K.R. 2017. Corruption and Governance in Africa: Swaziland, Kenya, Nigeria. Switzerland: Palgrave Macmillan. https://doi.org/10.1007/9783-319-50191-8

Irobi, E. 1989. Inflorescence. Enugu: ABIC BOOKS.

Irobi, E. 2009. Cotyledons. Enugu. ABIC BOOKS.

Irobi, E. 2004. Rejection Slips. wwwothervoicespoetry.org/vol9/irobi/ (Accessed on 20 August 2019.)

Irobi, E. 2005. Why I Don't Like Philip Larkin \& Other Poems. United Kingdom: Nsibidi Africana Publishers.

Irobi, E. 2010. Kingdom of the Mad. Volume 3,4,July. www.sentinel poetry.org/vol 3/irobi/ (Accessed on 20 August 2019.)

Kanneh, K.1998. African Identities: Race, Nation and Culture in Ethnography,

Pan-Africanism and Black Literatures. London: Routledge.

Larson, C.R. 2001. The Ordeal of the African Writer. New York: Zed Books.

Mda, Z.1995. She Plays with the Darkness. Florida, RSA: Vivlia.

Mhlongo, N.2007. After Tears. Cape Town: Kwela.

Mitchell, W.J.T. 1994. Picture Theory: Essays on Verbal and Visual Representation. Chicago: University of Chicago Press.

Moele, K. 2006. Room207. Cape Town: Kwela.

Mpe, P. Welcome to Our Hillbrow 2001. Pietermaritzburg: University of Natal Press.

Nwankwo, A. 1967. Genocide not Internal Affair. Biafra Newsletter 3:25.

Obiechina, E. 1975. Culture, Tradition and Society in the West African Novel.

Cambridge: Cambridge University Press.

Oguibe, O. 2014. Esiaba Irobi: Tragedy of Exile. In Diala, I. (ed.): Syncretic

Arenas: Essays on Postcolonial African Drama and Theatre for Esiaba

Iroibi. New York: Rodopi.

Omotoso, Y. 2011. Bom Boy. Athlone: Modjaji Books.

Osha, S.1998. Writing in a Continent under Siege. Research in African Literatures 29,1: 174 - 178.

Osofisan, F. 1997. Playing Dangerously: Drama at the Frontiers of Terror in A 'Postcolonial' State. Inaugural Lecture, Faculty of Arts, University of Ibadan, 31 July 1997.

Schonstein, P.P. 2000. Skyline. Cape Town: David Philip.

Toivanen, A. 2011. At the Receiving End of Severe Misunderstanding: Dambudzo Marechera's Representations of Authorship. Research in African Literatures 42,1: 14 - 31. 
Niyi Akingbe

https://doi.org/10.2979/RAL.2011.42.1.14

Troost, H. 2007. Plot Loss. Roggebaai: Umuzi.

Wilson-Tagoe, N. 2009. New Locations and Changing Paradigms in Contemporary African Literature. In De Meyer, B. \& N. ten Kortenaar (eds.): The Changing Face of African Literature. Amsterdam-New York: Rodopi.

Niyi Akingbe Department of English Studies University of South Africa Pretoria South Africa deniakingbe@yahoo.com 